\title{
羟基磷灰石包覆 $\gamma-\mathrm{Fe}_{2} \mathrm{O}_{3}$ 担载氧化钼: 一种新型磁性可回收的 烯烃环氧化多相催化剂
}

\author{
袁程远 ${ }^{1,2}$, 张 奸 ${ }^{1}$, 陈 静 ${ }^{1, *}$ \\ ${ }^{1}$ 中国科学院兰州化学物理研究所羰基合成和选择氧化国家重点实验室, 甘肃兰州 730000 \\ 2 中国科学院研究生院, 北京 1000049
}

\begin{abstract}
摘要: 制备了羟基磷灰石 (HAP) 包覆纳米 $\gamma-\mathrm{Fe}_{2} \mathrm{O}_{3}$ 颗粒复合材料 ( $\mathrm{HAP}-\gamma-\mathrm{Fe}_{2} \mathrm{O}_{3}$ ), 并进一步采用浸渍法担载氧化锄 $\left(\mathrm{MoO}_{x} / \mathrm{HAP}-\gamma-\mathrm{Fe}_{2} \mathrm{O}_{3}\right)$. 高分辨透射电镜结果表明, $\gamma-\mathrm{Fe}_{2} \mathrm{O}_{3}$ 纳米颗粒被包覆于 $\mathrm{HAP}$ 当中, 平均粒径为 $1 \sim 3 \mathrm{~nm}$. 所制备催化剂对 以叔丁基过氧化氢为氧化剂的烯烃环氧化反应显示了良好的催化活性. 此外, 催化剂的可磁力分离特性为反应后催化剂的分 离回收提供了一种方便、快捷的途径. 催化剂可重复使用至少 5 次以上而没有显著的活性下降.
\end{abstract}

关键词：羟基磷灰石；环氧化；叔丁基过氧化氢；负载型钿基催化剂；磁力分离

中图分类号: O643 文献标识码: A

收稿日期: 2011-02-21. 接受日期: 2011-03-18.

*通讯联系人. 电话: (0931)4968068; 电子信箱: chenj@1zb.ac.cn

基金来源: 国家杰出青年科学基金 (20625308).

本文的英文电子版(国际版)由Elsevier出版社在ScienceDirect上出版(http://www.sciencedirect.com/science/journal/18722067).

\section{Molybdenum Oxide Supported on Hydroxyapatite-Encapsulated $\gamma-\mathrm{Fe}_{2} \mathrm{O}_{3}$ : A Novel Magnetically Recyclable Catalyst for Olefin Epoxidation}

\author{
YUAN Chengyuan ${ }^{1,2}$, ZHANG Yan $^{1}$, CHEN Jing ${ }^{1, *}$ \\ ${ }^{1}$ State Key Laboratory for Oxo Synthesis and Selective Oxidation, Lanzhou Institute of Chemical Physics, \\ Chinese Academy of Sciences, Lanzhou 730000, Gansu, China \\ ${ }^{2}$ Graduate University of Chinese Academy of Sciences, Beijing 100049, China
}

\begin{abstract}
Hydroxyapatite-encapsulated magnetic $\gamma-\mathrm{Fe}_{2} \mathrm{O}_{3}\left(\mathrm{HAP}-\gamma-\mathrm{Fe}_{2} \mathrm{O}_{3}\right)$ was synthesized and used as catalyst support. Molybdenum oxide nanoparticles were supported on $\mathrm{HAP}-\gamma-\mathrm{Fe}_{2} \mathrm{O}_{3}$ by incipient wetness impregnation $\left(\mathrm{MoO}_{x} / \mathrm{HAP}-\gamma-\mathrm{Fe}_{2} \mathrm{O}_{3}\right)$. High-resolution transmission electron microscopy characterization demonstrated the formation of $\gamma-\mathrm{Fe}_{2} \mathrm{O}_{3}$ nanocrystallites with a mean diameter of 1-3 nm within the HAP matrix. The molybdenum oxide dispersed on the surface of $\mathrm{HAP}-\gamma-\mathrm{Fe}_{2} \mathrm{O}_{3}$ showed good catalytic activities for the epoxidation of various olefins with tert-butyl hydroperoxide as oxidant. The magnetism of $\mathrm{MoO}_{x} / \mathrm{HAP}-\gamma-\mathrm{Fe}_{2} \mathrm{O}_{3}$ provided a convenient route for the separation of the catalyst from the reaction mixture by a magnet. The catalyst was recycled at least five times without appreciable loss of catalytic activity.
\end{abstract}

Key words: hydroxyapatite; epoxidation; tert-butyl hydroperoxide; supported molybdenum catalyst; magnetic separation

Received 21 February 2011. Accepted 18 March 2011.

*Corresponding author.Tel: +86-931-4968068; E-mail: chenj@lzb.ac.cn

This work was supported by the National Science Fund for Distinguished Young Scholars of China (20625308).

English edition available online at Elsevier ScienceDirect (http://www.sciencedirect.com/science/journal/18722067).

Olefin epoxidation is an important reaction because epoxides are very useful intermediates in the organic synthesis of fine chemicals [1]. Molybdenum (VI) solid catalysts are widely used for the epoxidation of olefins [2-8]. However, the catalysts can only be recycled by tedious procedures using filtration and centrifugation, which inevitably leads to the loss of catalyst in the separation processes. Recently, magnetic nanoparticles of iron oxides have received grow- 
ing attention due to their unique properties and potential application in various fields, such as magnetic resonance imaging (MRI) contrast agents, magnetically assisted drug delivery, hyperthermia, magnetic separation of biomolecules, and isolation and recycling of catalysts [9-12]. Magnetic separation is a convenient method for separating magnetic solid catalysts for recycling. However, bare nanoparticles of iron oxides tend to aggregate into large clusters and lose their single-domain and magnetic nanostructures. Therefore, a suitable passive material such as a polymer, carbon, or silica has to be coated on the surface of the iron oxide nanoparticles to prevent aggregation and improve their chemical stability [13-15].

Hydroxyapatites (HAPs) with the molecular formula of $\mathrm{Ca}_{10}\left(\mathrm{PO}_{4}\right)_{6}(\mathrm{OH})_{2}$ are of considerable interest for their structural stability, ionic substitution, and adsorption capacity [16]. The hexagonal apatite structure is composed of $\mathrm{Ca}^{2+}$ sites surrounded by tetrahedral $\mathrm{PO}_{4}{ }^{3-}$ units. $\mathrm{OH}^{-}$ions occupy columns parallel to the hexagonal structure. HAP has these unique advantages as a catalyst support: (1) a high ion-exchange ability and adsorption capacity, which are good for immobilizing active species; (2) a nonporous structure to avoid the problem of mass transfer limitation; and (3) weak acid-base properties that reduce side reactions induced by the support itself. HAP-encapsulated magnetic nanocrystallites as the catalyst support for olefin oxidation, alcohol oxidation, and dehalogenation reactions have been reported [17-19].

In this paper, we report the fabrication of molybdenum oxide nanoparticles dispersed on a hydroxyapatite shell that was coated on magnetic iron oxides particles. This was a highly active and magnetically recyclable catalyst for the epoxidation of alkene with tert-butyl hydroperoxide (TBHP).

\section{Experimental}

\subsection{Catalyst preparation}

The synthesis procedure is represented in Scheme 1. HAP-encapsulated $\gamma-\mathrm{Fe}_{2} \mathrm{O}_{3}\left(\mathrm{HAP}-\gamma-\mathrm{Fe}_{2} \mathrm{O}_{3}\right)$ was prepared according to a previously reported method [18]. The detailed procedure was as follows. $\mathrm{FeCl}_{2} \cdot 4 \mathrm{H}_{2} \mathrm{O}(1.85 \mathrm{mmol})$ and $\mathrm{FeCl}_{3} \cdot 6 \mathrm{H}_{2} \mathrm{O}(3.7 \mathrm{mmol})$ were dissolved in deionized water $(30 \mathrm{ml})$ under an Ar atmosphere at room temperature. The resulting solution was added to a $25 \mathrm{wt} \% \mathrm{NH}_{4} \mathrm{OH}$ solution $(10 \mathrm{ml})$ under vigorous mechanical stirring (300 r/min). A black precipitate of $\mathrm{Fe}_{3} \mathrm{O}_{4}$ was produced. In order to get small and uniform $\mathrm{Fe}_{3} \mathrm{O}_{4}$ particles, the drop rate of $\mathrm{NH}_{4} \mathrm{OH}$ was controlled precisely by a constant dropper. The drop time was $10 \mathrm{~min}$. After $15 \mathrm{~min}, 100 \mathrm{ml}$ of $\mathrm{Ca}\left(\mathrm{NO}_{3}\right)_{2} \cdot 4 \mathrm{H}_{2} \mathrm{O}$ (33.7 mmol, $0.5 \mathrm{~mol} / \mathrm{L})$ and $\left(\mathrm{NH}_{4}\right)_{2} \mathrm{HPO}_{4}(20 \mathrm{mmol}, 3.0$ $\mathrm{mol} / \mathrm{L}$ ) solutions with their $\mathrm{pH}$ adjusted to 11 were added dropwise to the precipitate over $30 \mathrm{~min}$ under mechanical stirring. The resulting milky solution was heated to $90{ }^{\circ} \mathrm{C}$. After $2 \mathrm{~h}$, the mixture was cooled to room temperature and aged overnight. The dark brown precipitate formed was filtered, washed repeatedly with deionized water until the water was neutral, and then air dried under vacuum at room temperature. The synthesized sample was calcined at $300{ }^{\circ} \mathrm{C}$ for $3 \mathrm{~h}$. The color of the powder changed from deep black to reddish-brown after calcination, indicating the transformation of the magnetite $\left(\mathrm{Fe}_{3} \mathrm{O}_{4}\right)$ cores to hematite $\left(\mathrm{Fe}_{2} \mathrm{O}_{3}\right)$.

The $\mathrm{MoO}_{x} / \mathrm{HAP}-\gamma-\mathrm{Fe}_{2} \mathrm{O}_{3}$ catalyst was prepared by incipient wetness impregnation. The required amount of $\left(\mathrm{NH}_{4}\right)_{6} \mathrm{Mo}_{7} \mathrm{O}_{24} \cdot 4 \mathrm{H}_{2} \mathrm{O}$ was dissolved in distilled water. HAP$\gamma-\mathrm{Fe}_{2} \mathrm{O}_{3}(1.0 \mathrm{~g})$ was added into the stirred solution at $80{ }^{\circ} \mathrm{C}$, and the water was completely evaporated. The $\mathrm{MoO}_{x} / \mathrm{HAP}-$ $\gamma-\mathrm{Fe}_{2} \mathrm{O}_{3}$ catalyst was obtained after the solid material was calcined at $550{ }^{\circ} \mathrm{C}$ for $3 \mathrm{~h}$ in air.

\subsection{Catalyst characterization}

X-ray diffraction (XRD) was carried out on a PANalytical X'pert Pro diffractometer. X-ray photoelectron spectroscopy (XPS) was performed on a VG ESCALAB 210 spectrometer. All binding energies were calibrated using the $\mathrm{C} 2 p$ peak at $285.0 \mathrm{eV}$. Transmission electron microscopy (TEM) images were obtained on a Hitachi H-600 electron microscope. High-resolution TEM (HRTEM) micrographs were obtained with a JEM-2010 electron microscope. BET surface area measurements were performed on a Micromeritics ASAP 2010 instrument at liquid nitrogen temperature. Magnetic properties were characterized by a VSM by Lakeshore 7304. The magnetism of $\mathrm{HAP}-\gamma-\mathrm{Fe}_{2} \mathrm{O}_{3}$ was investigated using a superconducting quantum interface device magne-

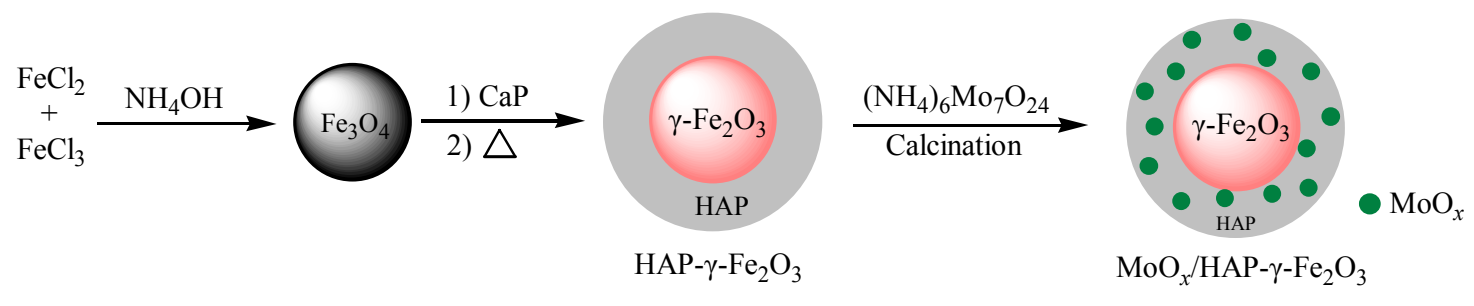

Scheme 1. Synthesis of $\mathrm{MoO}_{x} / \mathrm{HAP}-\gamma-\mathrm{Fe}_{2} \mathrm{O}_{3}$. 
tometer.

\subsection{Catalytic tests}

The activity of the $\mathrm{MoO}_{x} / \mathrm{HAP}-\gamma-\mathrm{Fe}_{2} \mathrm{O}_{3}$ catalyst was tested with the epoxidation of olefin. In a typical experiment, a mixture of substrate ( $5 \mathrm{mmol}$ ), TBHP (70 wt $\%, 5$ $\mathrm{mmol}$ ), and $25 \mathrm{mg}$ of $\mathrm{MoO}_{x} / \mathrm{HAP}-\gamma-\mathrm{Fe}_{2} \mathrm{O}_{3}$ in $6 \mathrm{ml}$ chloroform was introduced into a $50 \mathrm{ml}$ glass reactor with vigorous stirring. The reaction was maintained for $8 \mathrm{~h}$ to get a high conversion. Qualitative analysis was conducted with a HP 6890/5973 GCMS with Chemstation and the NIST mass spectral database. Quantitative analysis was conducted with an Agilent 6820 GC equipped with an FID.

The reusability of the catalyst was tested as follows. After the reaction, a bar magnet was used to keep the $\mathrm{MoO}_{x} /$ HAP $-\gamma-\mathrm{Fe}_{2} \mathrm{O}_{3}$ catalyst on the side wall of the reactor while the reaction solution was removed. The catalyst was washed repeatedly with chloroform. Alkene, chloroform, and TBHP were then added to start the next run.

\section{Results and discussion}

\subsection{Characterization results}

\subsubsection{Textural, chemical, and physical properties}

Figure 1 shows the nitrogen adsorption-desorption isotherms of the samples. All samples showed a Type IV isotherm with a Type $\mathrm{H} 2$ hysteresis loop, indicating the presence of well-developed mesoporosity in all the samples.

Table 1 summarizes the physicochemical parameters of the catalysts. As compared with $\mathrm{HAP}-\gamma-\mathrm{Fe}_{2} \mathrm{O}_{3}$, the BET

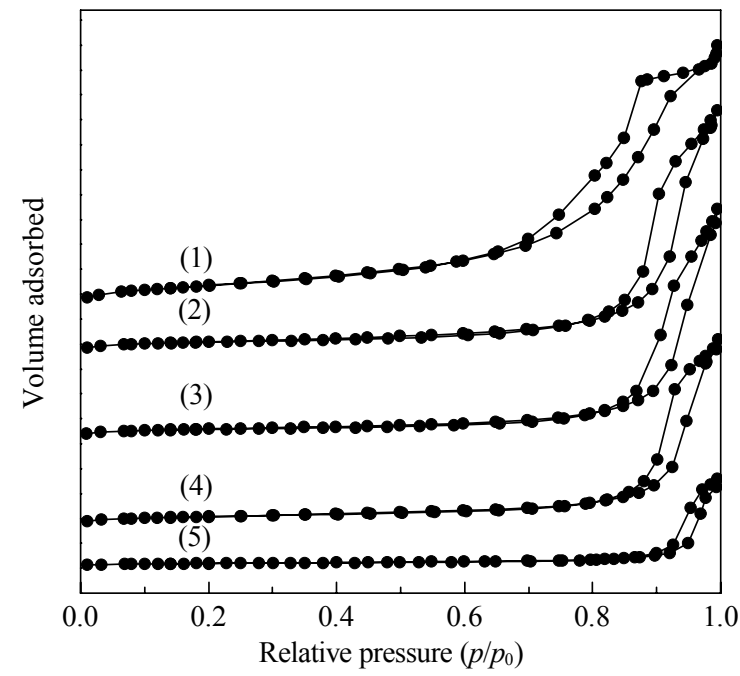

Fig. 1. $\mathrm{N}_{2}$ adsorption-desorption isotherms of HAP- $\gamma-\mathrm{Fe}_{2} \mathrm{O}_{3}$ (1), 5 $\mathrm{wt} \% \mathrm{MoO}_{x} / \mathrm{HAP}-\gamma-\mathrm{Fe}_{2} \mathrm{O}_{3}$ (2), $10 \mathrm{wt} \% \mathrm{MoO}_{x} / \mathrm{HAP}-\gamma-\mathrm{Fe}_{2} \mathrm{O}_{3}$ (3), 20 $\mathrm{wt} \% \mathrm{MoO}_{x} / \mathrm{HAP}-\gamma-\mathrm{Fe}_{2} \mathrm{O}_{3}(4)$, and $30 \mathrm{wt} \% \mathrm{MoO}_{x} / \mathrm{HAP}-\gamma-\mathrm{Fe}_{2} \mathrm{O}_{3}(5)$.
Table 1 Textural parameters of the catalyst samples

BET surface Pore volume Pore diameter

Sample

$\mathrm{HAP}-\gamma-\mathrm{Fe}_{2} \mathrm{O}_{3}$ area $\left(\mathrm{m}^{2} / \mathrm{g}\right) \quad\left(\mathrm{cm}^{3} / \mathrm{g}\right) \quad(\mathrm{nm})$

$5 \mathrm{wt} \% \mathrm{MoO}_{x} / \mathrm{HAP}-\gamma-\mathrm{Fe}_{2} \mathrm{O}_{3}$

$10 \mathrm{wt} \% \mathrm{MoO}_{x} / \mathrm{HAP}-\gamma-\mathrm{Fe}_{2} \mathrm{O}_{3}$

$20 \mathrm{wt} \% \mathrm{MoO}_{x} / \mathrm{HAP}-\gamma-\mathrm{Fe}_{2} \mathrm{O}_{3}$

0.43

$\begin{array}{lll}59 & 0.39 & 26.2\end{array}$

$\begin{array}{lll}48 & 0.36 & 28.7\end{array}$

$30 \mathrm{wt} \% \mathrm{MoO}_{x} / \mathrm{HAP}-\gamma-\mathrm{Fe}_{2} \mathrm{O}_{3} \quad 16 \quad 0.14 \quad 34.3$

surface area and specific pore volume of $\mathrm{MoO}_{x} / \mathrm{HAP}-$ $\gamma-\mathrm{Fe}_{2} \mathrm{O}_{3}$ were obviously smaller while the pore diameter was increased. This was because molybdenum oxide particles have blocked some of the pores when they were deposited, which suggested that molybdenum oxide can be easily fixed on the surface of HAP- $\gamma-\mathrm{Fe}_{2} \mathrm{O}_{3}$ by conventional incipient wetness impregnation. It should be noted that the changes in BET surface area, specific pore volume, and pore diameter increased abruptly when the Mo loading exceeded $20 \mathrm{wt} \%$, which was attributed to the agglomeration of molybdenum oxide.

\subsubsection{XRD}

The powder XRD patterns of HAP, HAP- $\gamma-\mathrm{Fe}_{2} \mathrm{O}_{3}$, $\mathrm{Mo} / \mathrm{HAP}-\gamma-\mathrm{Fe}_{2} \mathrm{O}_{3}$, and $\mathrm{MoO}_{3}$ samples are shown in Fig. 2 . Seven well-resolved diffraction peaks of pure HAP $(2 \theta=$ $25.9^{\circ}, 31.8^{\circ}, 32.9^{\circ}, 34.1^{\circ}, 39.8^{\circ}, 46.7^{\circ}$, and $\left.49.5^{\circ}\right)$ were

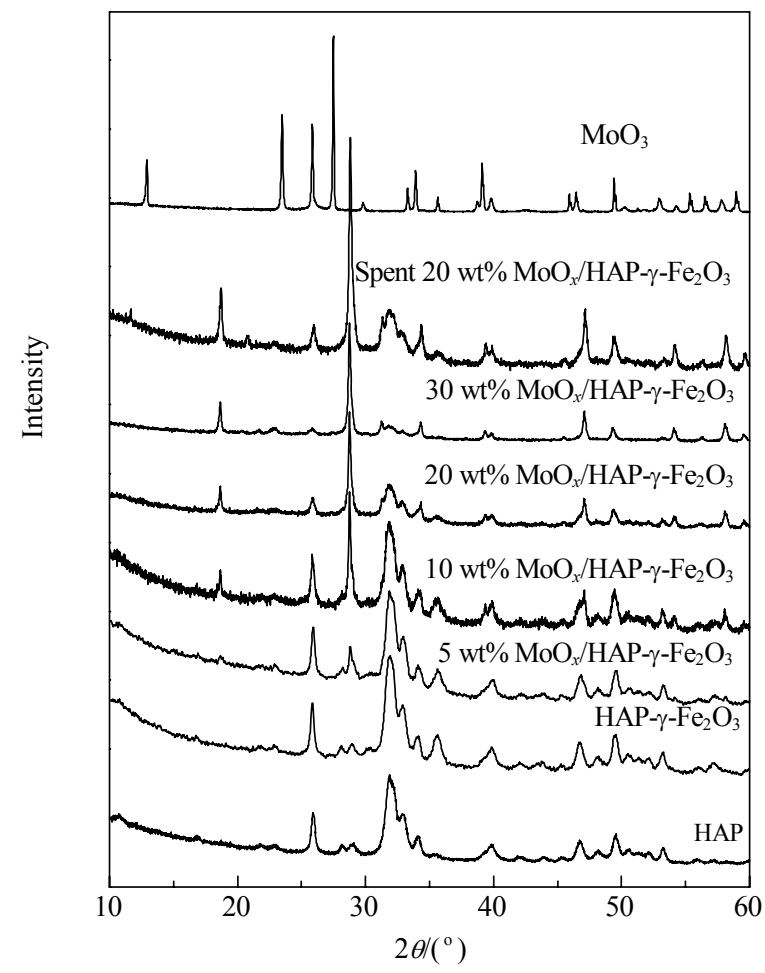

Fig. 2. XRD patterns of $\mathrm{HAP}, \mathrm{HAP}-\gamma-\mathrm{Fe}_{2} \mathrm{O}_{3}, \mathrm{MoO}_{x} / \mathrm{HAP}-\gamma-\mathrm{Fe}_{2} \mathrm{O}_{3}$, and $\mathrm{MoO}_{3}$. 
clearly observed with $\mathrm{HAP}-\gamma-\mathrm{Fe}_{2} \mathrm{O}_{3}$ and all the $\mathrm{MoO}_{x} / \mathrm{HAP}-$ $\gamma-\mathrm{Fe}_{2} \mathrm{O}_{3}$ catalysts, confirming the formation of the HAP phase. The diffraction peaks of $\mathrm{HAP}-\gamma-\mathrm{Fe}_{2} \mathrm{O}_{3}$ were weak, which was probably due to the small size of the particles [18]. As compared with pure $\gamma-\mathrm{Fe}_{2} \mathrm{O}_{3}[20,21]$, $\mathrm{HAP}-\gamma-\mathrm{Fe}_{2} \mathrm{O}_{3}$ exhibited clear diffraction peaks at $2 \theta=30.2^{\circ}, 35.7^{\circ}$, and $43.6^{\circ}$, which were assigned to the (220), (311), and (400) reflections of $\gamma-\mathrm{Fe}_{2} \mathrm{O}_{3}$, respectively. Other iron oxide phases such as $\alpha-\mathrm{Fe}_{2} \mathrm{O}_{3}\left(2 \theta=24.1^{\circ}, 33.1^{\circ}, 35.6^{\circ}, 40.8^{\circ}, 54.1^{\circ}\right.$, and $\left.63.9^{\circ}\right)$ were not detected. The diffraction line of $\mathrm{MoO}_{3}$ was absent in the diffractograms of the catalysts with Mo content lower than $30 \mathrm{wt} \%$. It is worth noting that two new diffraction peaks at $2 \theta=18.5^{\circ}$ and $28.7^{\circ}$ appeared with all the $\mathrm{MoO}_{x} / \mathrm{HAP}-\gamma-\mathrm{Fe}_{2} \mathrm{O}_{3}$ catalysts, which were not seen with $\mathrm{HAP}-\gamma-\mathrm{Fe}_{2} \mathrm{O}_{3}$ and $\mathrm{MoO}_{3}$. The appearance of these two new peaks indicated that molybdenum oxide phases that were different from $\mathrm{MoO}_{3}$ were formed on the surface of the $\mathrm{MoO}_{x} / \mathrm{HAP}-\gamma-\mathrm{Fe}_{2} \mathrm{O}_{3}$ catalysts. As compared with the fresh catalyst, there was no change in the characteristic diffraction peaks of the spent $\mathrm{MoO}_{x} / \mathrm{HAP}-\gamma-\mathrm{Fe}_{2} \mathrm{O}_{3}$ catalyst after six recycles, indicating the high stability of the catalyst.

\subsubsection{XPS}

XPS binding energies and intensities of the surface elements provide information on the chemical states and relative quantities of the surface compounds. Figure 3 shows the Mo $3 d$ spectra of the $\mathrm{MoO}_{x} / \mathrm{HAP}-\gamma-\mathrm{Fe}_{2} \mathrm{O}_{3}$ catalysts as a function of molybdenum content. Assignment of the Mo on the supports was possible using the spectra of pure $\mathrm{MoO}_{3}$ as reference. The Mo binding energies in $\mathrm{MoO}_{3}\left(E_{\mathrm{b}}\left(\mathrm{Mo} 3 d_{5 / 2}\right)\right.$ $=233.1 \mathrm{eV}, E_{\mathrm{b}}\left(\right.$ Mo $\left.3 d_{3 / 2}\right)=236.2 \mathrm{eV}$ ) were similar to that of the $\mathrm{MoO}_{x} / \mathrm{HAP}-\gamma-\mathrm{Fe}_{2} \mathrm{O}_{3}$ catalysts. As compared with pure $\mathrm{MoO}_{3}$, the Mo binding energies of all the $\mathrm{MoO}_{x} / \mathrm{HAP}$ -

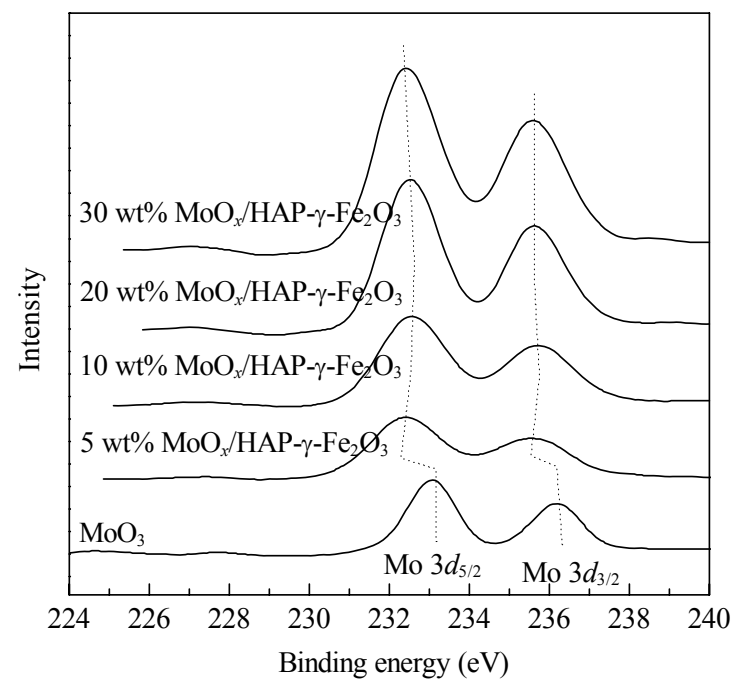

Fig. 3. XPS spectra of the Mo $3 d$ region for different $\mathrm{MoO}_{x} / \mathrm{HAP}$ $\gamma-\mathrm{Fe}_{2} \mathrm{O}_{3}$ catalysts and $\mathrm{MoO}_{3}$.
$\gamma-\mathrm{Fe}_{2} \mathrm{O}_{3}$ catalysts with different Mo loadings were shifted to lower binding energies, indicating that there was electron transfer from the support to the Mo species on the surface of the catalysts. This result also confirmed that there existed chemical interactions between Mo and the HAP- $\gamma-\mathrm{Fe}_{2} \mathrm{O}_{3}$ support, which was consistent with the XRD result. The energy of the Mo $3 d_{5 / 2}$ signal from the $\mathrm{MoO}_{x} / \mathrm{HAP}-\gamma-\mathrm{Fe}_{2} \mathrm{O}_{3}$ catalyst was $232.5 \mathrm{eV}$, which agreed with that of $\mathrm{MoO}_{4}{ }^{2-}$ reported previously [22]. Therefore, the main Mo peak of this catalyst was explained by the presence of a mixture of $\mathrm{MoO}_{3}$ and $\mathrm{MoO}_{4}{ }^{2-}$. In addition, as seen from Fig. 3, the XPS signal intensity of Mo $3 d$ increased with Mo content.

\subsubsection{HRTEM}

Figure 4 shows the HRTEM images. Figure 4(a) showed a clear image that $\gamma-\mathrm{Fe}_{2} \mathrm{O}_{3}$ was coated with a layer HAP. The $\gamma-\mathrm{Fe}_{2} \mathrm{O}_{3}$ nanocrystallites were uniformly distributed within the host HAP matrix with diameters of $1-3 \mathrm{~nm}$, which were smaller than those in the results reported by Mori et al. [18]. The micrograph of $20 \mathrm{wt} \% \mathrm{MoO}_{x} / \mathrm{HAP}-$ $\gamma-\mathrm{Fe}_{2} \mathrm{O}_{3}$ is shown in Fig. 4(b). Dark amorphous nano-particles of molybdenum oxide with a size distribution of 20-50 nm existed on the surface of HAP, which was consistent with the XRD result. The diffraction pattern (the inset in Fig. 4(a)) exhibited atomic lattice fringes corresponding to the (220), (311), and (400) planes of $\gamma-\mathrm{Fe}_{2} \mathrm{O}_{3}$,

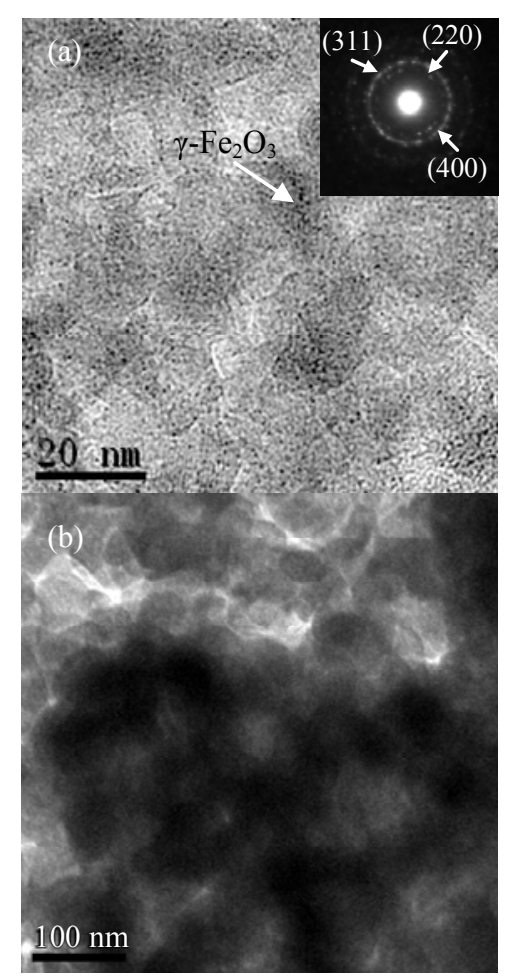

Fig. 4. HRTEM images of $\mathrm{HAP}-\gamma-\mathrm{Fe}_{2} \mathrm{O}_{3}$ (a) and $20 \mathrm{wt} \% \mathrm{MoO}_{x} /$ $\mathrm{HAP}-\gamma-\mathrm{Fe}_{2} \mathrm{O}_{3}$ (b). 
which was in good agreement with those obtained from XRD described earlier [23].

\subsubsection{Magnetic hysteresis loop}

Figure 5 shows the magnetic hysteresis loop of HAP- $\gamma-\mathrm{Fe}_{2} \mathrm{O}_{3}$. As shown in Fig. 5, the isothermal magnetization curve of $\mathrm{HAP}-\gamma-\mathrm{Fe}_{2} \mathrm{O}_{3}$ displayed a rapid increase with increasing applied magnetic field, with a saturation magnetization $\left(M_{\mathrm{s}}\right)$ value of $7 \mathrm{emu} / \mathrm{g}$. Taken into consideration the $\gamma-\mathrm{Fe}_{2} \mathrm{O}_{3}$ content in the sample (12 $\mathrm{wt} \%$ ), the $M_{\mathrm{s}}$ value of $58 \mathrm{emu} / \mathrm{g}$ for $\gamma-\mathrm{Fe}_{2} \mathrm{O}_{3}$ encapsulated in the mesoporous titanium-silica shell was smaller than the theoretical $M_{\mathrm{s}}$ value of $76 \mathrm{emu} / \mathrm{g}$ for bulk $\gamma-\mathrm{Fe}_{2} \mathrm{O}_{3}$ [24], which can be explained by the size effect degradation of the magnetic properties of iron oxide nanocrystallites [25].

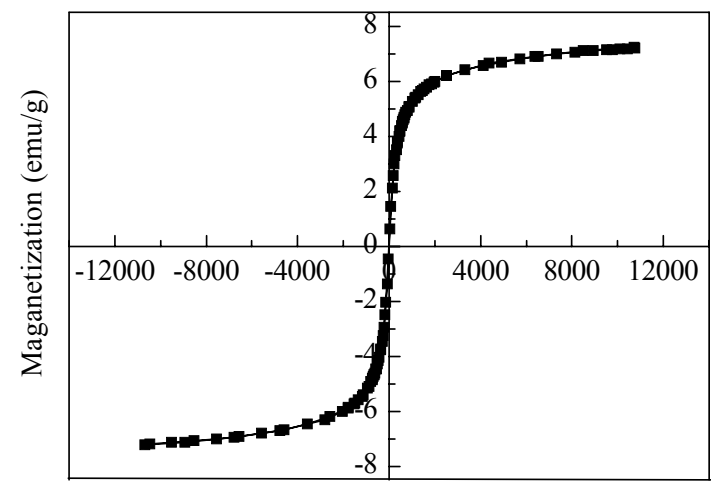

Field (Oe)

Fig. 5. Magnetic hysteresis loop of $\mathrm{HAP}-\gamma-\mathrm{Fe}_{2} \mathrm{O}_{3}$.

\subsection{Catalytic test}

The catalytic activities of the various catalysts for the epoxidation of cyclohexene under different reaction conditions are shown in Table 2. In the absence of a catalyst (entry 1 ), cyclohexene gave only $27.1 \%$ conversion and no epoxide was found. Since the carrier of $\mathrm{HAP}-\gamma-\mathrm{Fe}_{2} \mathrm{O}_{3}$ gave a similar result to that with no catalyst, the carrier was not active (entry 2 ).

$\mathrm{MoO}_{x} / \mathrm{HAP}-\gamma-\mathrm{Fe}_{2} \mathrm{O}_{3}$ gave very high conversion and epoxide selectivity, which indicated that molybdenum oxide was the active component and confirmed the existence of molybdenum oxide on the surface of $\mathrm{MoO}_{x} / \mathrm{HAP}-\gamma-\mathrm{Fe}_{2} \mathrm{O}_{3}$. The catalytic performances over various molybdenum-containing catalysts with different molybdenum content were tested (entries 3-6). When the molybdenum content increased from $5 \mathrm{wt} \%$ to $20 \mathrm{wt} \%$, the cyclohexene conversion and epoxide selectivity increased gradually. However, when the molybdenum content was $>20 \mathrm{wt} \%$, the epoxide selectivity decreased, which was probably due to the increase of side reactions caused by the agglomeration of molybdenum oxide. $20 \mathrm{wt} \% \mathrm{MoO}_{x} / \mathrm{HAP}-\gamma-\mathrm{Fe}_{2} \mathrm{O}_{3}$ showed $90.8 \%$ cyclohexene conversion and $98.7 \%$ epoxide selectivity, which were higher than those reported previously for this reaction using Mo-based catalysts [2-6]. Taking into account the cyclohexene conversion as well as the epoxide selectivity, $20 \mathrm{wt} \% \mathrm{MoO}_{x} / \mathrm{HAP}-\gamma-\mathrm{Fe}_{2} \mathrm{O}_{3}$ was the best for the epoxidation of cyclohexene.

Various solvents were examined to find the appropriate conditions for the reaction (entries 5, 7-9). The performance of this catalyst was significantly solvent dependent, with $\mathrm{CHCl}_{3}$ giving the best result.

The temperature dependence of cyclohexene epoxidation was also investigated (entries 5, 10, and 11). Cyclohexene conversion and epoxide selectivity strongly depended on the reaction temperature, which was consistent with the results in a previous report [26]. When the reaction was performed at $30{ }^{\circ} \mathrm{C}$, the conversion of cyclohexene and selectivity for epoxide were very low. As the temperature increased, both the conversion of cyclohexene and selectivity for epoxide increased. A cyclohexene conversion of $90.8 \%$ and epoxide selectivity of $98.7 \%$ were obtained at $70{ }^{\circ} \mathrm{C}$.

The present catalyst afforded a simple way for separating

Table 2 Epoxidation of cyclohexene under various reaction conditions

\begin{tabular}{rccccc}
\hline Entry & Catalyst & Solvent & Temperature $\left({ }^{\circ} \mathrm{C}\right)$ & Conversion (\%) & Epoxide selectivity (\%) \\
\hline 1 & blank & $\mathrm{CHCl}_{3}$ & 70 & 27.1 & - \\
2 & $\mathrm{HAP}-\gamma-\mathrm{Fe}_{2} \mathrm{O}_{3}$ & $\mathrm{CHCl}_{3}$ & 70 & 33.9 & - \\
3 & $5 \mathrm{wt} \% \mathrm{MoO}_{x} / \mathrm{HAP}-\gamma-\mathrm{Fe}_{2} \mathrm{O}_{3}$ & $\mathrm{CHCl}_{3}$ & 70 & 46.1 & 51.8 \\
4 & $10 \mathrm{wt} \% \mathrm{MoO}_{x} / \mathrm{HAP}-\gamma-\mathrm{Fe}_{2} \mathrm{O}_{3}$ & $\mathrm{CHCl}_{3}$ & 70 & 68.9 & 89.0 \\
5 & $20 \mathrm{wt} \% \mathrm{MoO}_{x} / \mathrm{HAP}-\gamma-\mathrm{Fe}_{2} \mathrm{O}_{3}$ & $\mathrm{CHCl}_{3}$ & 70 & 90.8 & 98.7 \\
6 & $30 \mathrm{wt} \% \mathrm{MoO}_{x} / \mathrm{HAP}-\gamma-\mathrm{Fe}_{2} \mathrm{O}_{3}$ & $\mathrm{CHCl}_{3}$ & 70 & 93.4 & 45.6 \\
7 & $20 \mathrm{wt} \% \mathrm{MoO}_{x} / \mathrm{HAP}-\gamma-\mathrm{Fe}_{2} \mathrm{O}_{3}$ & $\mathrm{C}_{6} \mathrm{H}_{14}$ & 70 & 25.7 & - \\
8 & $20 \mathrm{wt} \% \mathrm{MoO}_{x} / \mathrm{HAP}-\gamma-\mathrm{Fe}_{2} \mathrm{O}_{3}$ & $\mathrm{CH}_{3} \mathrm{CN}$ & 70 & no reaction & - \\
9 & $20 \mathrm{wt} \% \mathrm{MoO}_{x} / \mathrm{HAP}-\gamma-\mathrm{Fe}_{2} \mathrm{O}_{3}$ & $\mathrm{CH}_{3} \mathrm{OH}$ & 70 & no reaction & 11.2 \\
10 & $20 \mathrm{wt} \% \mathrm{MoO}_{x} / \mathrm{HAP}-\gamma-\mathrm{Fe}_{2} \mathrm{O}_{3}$ & $\mathrm{CHCl}_{3}$ & 30 & 10.3 & 83.7 \\
11 & $20 \mathrm{wt} \% \mathrm{MoO}_{x} / \mathrm{HAP}-\gamma-\mathrm{Fe}_{2} \mathrm{O}_{3}$ & $\mathrm{CHCl}_{3}$ & 50 & 59.4 & \\
\hline
\end{tabular}

Reaction conditions: cyclohexene $5 \mathrm{mmol}$, TBHP $5 \mathrm{mmol}$, catalyst $25 \mathrm{mg}$, solvent $6 \mathrm{ml}, 8 \mathrm{~h}$. Conversion and selectivity for olefins were determined by GC using an internal standard (decane) technique. 
the catalyst from the reaction mixture due to the heterogeneous nature and magnetic properties of the catalyst. This is shown in Fig. 6. The catalyst was easily recoverable by using an external permanent magnet.

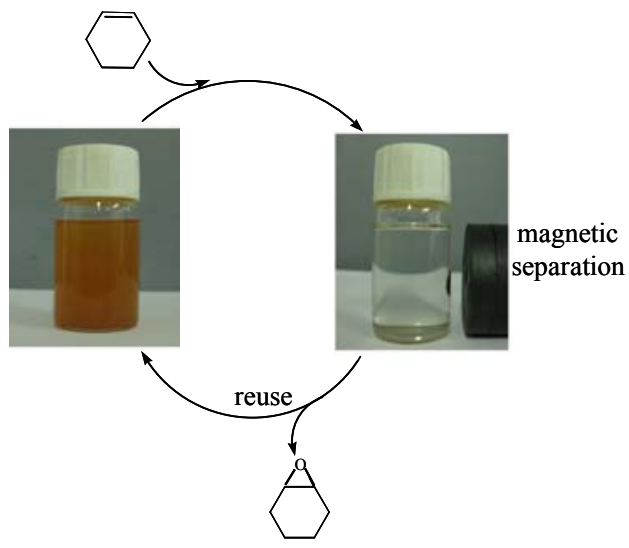

Fig. 6. Magnetic separation and recycling of the $\mathrm{MoO}_{x} / \mathrm{HAP}-\gamma-\mathrm{Fe}_{2} \mathrm{O}_{3}$ catalyst.

We also investigated the recycling of the catalyst. It was successfully recycled and reused six times in the epoxidation of cyclohexene with no significant loss of activity, as shown in Fig. 7. As can be seen, the conversion of cyclohexene and selectivity to epoxide were almost unchanged after six reaction cycles. ICP analysis of the filtrate confirmed that the metal contents in it were negligible (Mo $<5$ $\mu \mathrm{g} / \mathrm{L}, \mathrm{Fe}<3 \mu \mathrm{g} / \mathrm{L})$.

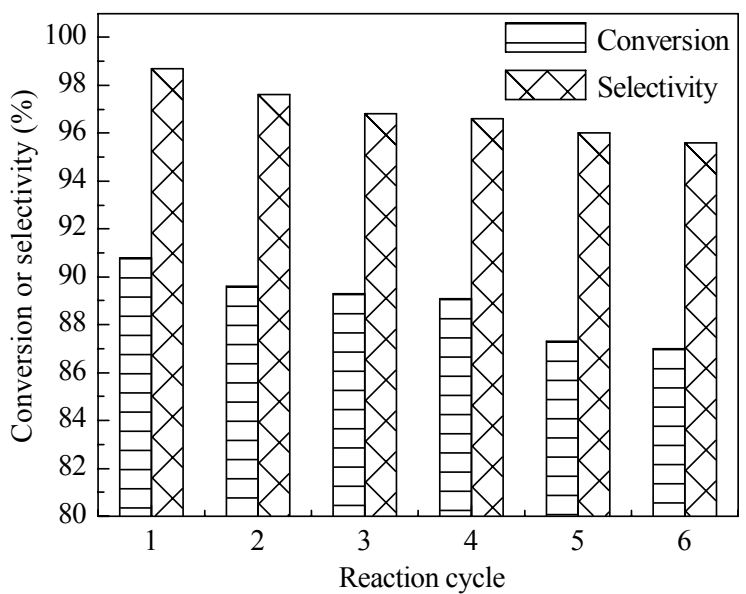

Fig. 7. Reuse of the $20 \mathrm{wt} \% \mathrm{MoO}_{x} / \mathrm{HAP}-\gamma-\mathrm{Fe}_{2} \mathrm{O}_{3}$ catalyst. Reaction conditions: cyclohexene $5 \mathrm{mmol}$, TBHP $5 \mathrm{mmol}$, catalyst $25 \mathrm{mg}$, $\mathrm{CHCH}_{3} 6 \mathrm{ml}, 70{ }^{\circ} \mathrm{C}, 8 \mathrm{~h}$.

To extend the scope of the catalyst, the $\mathrm{MoO}_{x} / \mathrm{HAP}$ $\gamma-\mathrm{Fe}_{2} \mathrm{O}_{3}$ catalyst was applied for the oxidation of a wide range of cyclic and linear alkenes with TBHP under the optimized conditions. As shown in Table 3, all of the olefins were converted into the corresponding epoxides with excellent conversions and epoxide selectivities.
Table 3 Epoxidation of olefins catalyzed by the $20 \mathrm{wt} \% \mathrm{MoO}_{x} / \mathrm{HAP}-$ $\gamma-\mathrm{Fe}_{2} \mathrm{O}_{3}$ catalyst

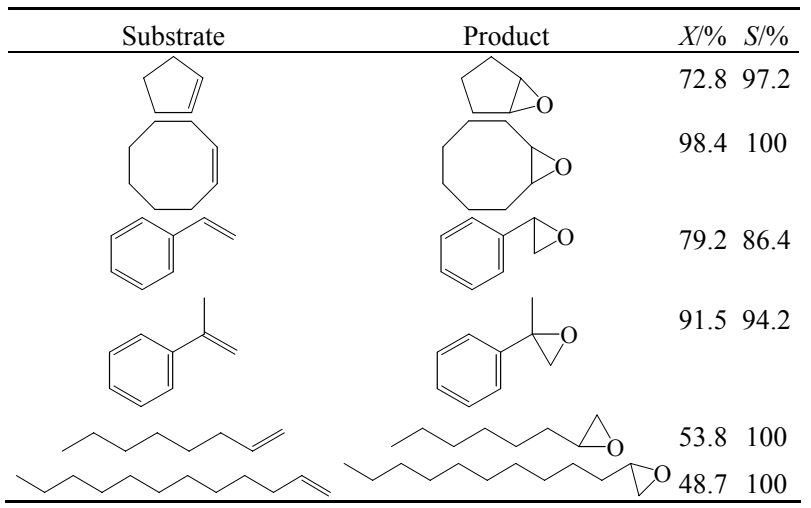

Reaction conditions: olefin $5 \mathrm{mmol}$, TBHP $5 \mathrm{mmol}$, catalyst $25 \mathrm{mg}$, $\mathrm{CHCH}_{3} 6 \mathrm{ml}, 70{ }^{\circ} \mathrm{C}, 8 \mathrm{~h}$. Conversion and selectivity for olefins were determined by $\mathrm{GC}$ using an internal standard (decane) technique.

\section{Conclusions}

We have developed a new magnetically recyclable and efficient nanocomposite catalyst for the epoxidation of olefins using molybdenum oxide nanoparticles supported on hydroxyapatite-encapsulated $\gamma-\mathrm{Fe}_{2} \mathrm{O}_{3}$ nanocrystallites. This catalyst showed several attractive features for practical applications. First, $\gamma-\mathrm{Fe}_{2} \mathrm{O}_{3}$ nanocrystallites were dispersed within the HAP matrix. Second, the magnetic core was protected by hydroxyapatite, which makes its use under harsh reaction conditions possible. Third, the magnetic core allowed the easy recovery and recycling of the catalyst with no significant loss of catalytic activity. This magnetic nanocomposite catalyst should find applications in many other industrially important catalytic processes.

\section{References}

1 Lane B S, Burgess K. Chem Rev, 2003, 103: 2457

2 Juwiler D, Neumann R. Catal Lett, 2001, 72: 241

3 Teixeira S, Dallmann K, Schuchardt U, Buffon R. J Mol Catal A, 2002, 182-183: 167

4 Jia M, Thiel W R. Chem Commun, 2002: 2392

5 Nunes C D, Pillinger M, Valente A A, Rocha J, Lopes A D, Goncalves I S. Eur J Inorg Chem, 2003, 21: 3870

6 Shokouhimehr M, Piao Y Z, Kim J Y, Jang Y J, Hyeon T W. Angew Chem, Int Ed, 2007, 46: 7039

7 吕正荣, 郭秋玲, 殷元骐, 金道森. 催化学报 (Lü Zh R, Guo Q L, Yin Y Q, Jin D S. Chin J Catal), 1992, 13: 198

8 王立, 马涛, 盛蔚, 郭学锋, 丁维平, 陈懿. 催化学报 (Wang L, Ma T, Sheng W, Guo X F, Ding W P, Chen Y. Chin J Catal), 2009, 30: 711

9 Morent S, Vasseur S, Grasset F, Duguet E. J Mater Chem, 2004, 14: 2161 
10 Astruc D, Lu F, Aranzaes J R. Angew Chem, Int Ed, 2005, 44: 7852

11 Melero J A, van Grieken R, Morales G. Chem Rev, 2006, 106: 3790

12 Liu J M, Peng X G, Sun W, Zhao Y W, Xia C G. Org Lett, 2008, 10: 3933

13 Yi D K, Lee S S, Ying J Y. Chem Mater, 2006, 18: 2459

14 Banerjee S S, Chen D H. Chem Mater, 2007, 19: 3667

15 Ye E Y, Liu B H, Fan W Y. Chem Mater, 2007, 19: 3845

16 Misra D N. J Adhes Sci Technol, 1994, 8: 87

17 Zhang Y, Li Z, Sun W, Xia C G. Catal Commun, 2008, 10: 237

18 Mori K, Kanai S, Hara T, Mizugaki T, Ebitani K, Jitsukawa K, Kaneda K. Chem Mater, 2007, 19: 1249
19 Hara T, Kaneta T, Mori K, Mitsudome T, Mizugaki T, Ebitani K, Kaneda K. Green Chem, 2007, 9: 1246

20 Dálaigh C Ó, Corr S A, Gun'ko Y, Connon S J. Angew Chem, Int $E d, 2007,46: 4329$

21 Abu-Rezip R, Alper H, Wang D, Post M L. J Am Chem Soc, 2006, 128: 5279

22 Grim S O, Matienzo L J. Inorg Chem, 1975, 14: 1014

23 Hyeon T, Lee S S, Park J, Chung Y, Na H B. J Am Chem Soc, 2001, 123: 12798

24 Cullity B D. Introduction to Magnetic Materials. Massachusetts: Addision-Wesley Reading, 1972. 201

25 Craik D. Magnetic Oxides. New York: Wiley, 1975. 697

26 Arnold U, da Cruz R S, Mandelli D, Schuchardt U. J Mol Catal A, 2001, 165: 149 